\title{
Dissecting the genetic architecture of coronary artery disease by genome engineering
}

\author{
David J Segal ${ }^{1 *}$, Mital S Bhakta ${ }^{1}$, Kumitaa Theva Das ${ }^{1}$, Chongxiu Sun ${ }^{2}$, Natalie M Grace ${ }^{1}$, Jan A Nolta ${ }^{3}$, \\ Anne A Knowlton ${ }^{4}$, David M Rocke ${ }^{5}$, Scott I Simon ${ }^{2}$ \\ From Beyond the Genome 2012 \\ Boston, MA, USA. 27-29 September 2012
}

One of the greatest challenges facing biomedical research since the sequencing of the human genome has been to understand the role of genetic variation in human disease. Many genetic variants have been associated with common diseases. However, determining the functional consequences of these variants has been hard. Several variants are often inherited together in tightly linked blocks, making it difficult to determine the causative variant. People have millions of other genetic differences, making it difficult to correlate cellular phenotypes with a particular variant. Different gene sets are expressed in different cells, but it is difficult to extract disease-relevant cells from large numbers of patients. We describe a method with the potential to revolutionize the functional analysis of genetic variation, using custom nucleases to genetically modify individual variants in induced pluripotent stem cells. This process would provide unprecedented analytical power, present the first general method to determine if a variant is causative, and analyze function disease-relevant cell types. We will focus on variants at the $9 \mathrm{p} 21$ region of the genome that have been associated with coronary artery disease (CAD). The methods should provide a new way to unlock the wealth of data from genome-wide association studies, and to probe the genetic architecture of common diseases. We will describe our improved methods for inexpensive and rapid construction of highly active zinc finger and TALE nucleases to examine the functional role of polymorphisms at the 9p21 CAD risk locus.

\section{Acknowledgement}

This work is generously supported by the W M Keck Foundation.

'Genome Center and Department of Molecular Medicine, University of California - Davis, Davis, CA 95616, USA

Full list of author information is available at the end of the article
Author details

'Genome Center and Department of Molecular Medicine, University of California - Davis, Davis, CA 95616, USA. ${ }^{2}$ Biomedical Engineering, University of California - Davis, Davis, CA 95616, USA. ${ }^{3}$ Institute for Regenerative Cures, University of California - Davis, Davis, CA 95616, USA. ${ }^{4}$ Cardiovascular Medicine, University of California - Davis, Davis, CA 95616, USA. ${ }^{5}$ Division of Biostatistics, University of California - Davis, Davis, CA 95616, USA.

Published: 1 October 2012

doi:10.1186/1753-6561-6-S6-P34

Cite this article as: Segal et al:: Dissecting the genetic architecture of coronary artery disease by genome engineering. BMC Proceedings 2012 6(Suppl 6):P34.
Submit your next manuscript to BioMed Central and take full advantage of:

- Convenient online submission

- Thorough peer review

- No space constraints or color figure charges

- Immediate publication on acceptance

- Inclusion in PubMed, CAS, Scopus and Google Scholar

- Research which is freely available for redistribution

Submit your manuscript at www.biomedcentral.com/submit
Biomed Central 